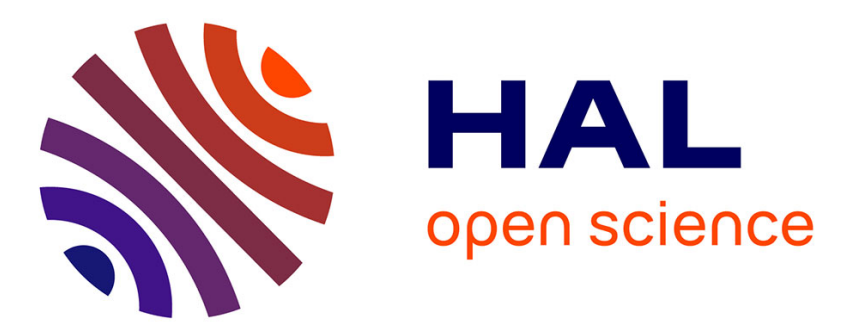

\title{
Characterizing deep hydrothermal fluid circulation in the Upper Rhine Graben (France) with electromagnetic methods
}

Mathieu Darnet

\section{- To cite this version:}

Mathieu Darnet. Characterizing deep hydrothermal fluid circulation in the Upper Rhine Graben (France) with electromagnetic methods. EAGE Annual Meeting, Oct 2021, Amsterdam, Netherlands. hal-03363169

\section{HAL Id: hal-03363169 https: / hal-brgm.archives-ouvertes.fr/hal-03363169}

Submitted on 3 Oct 2021

HAL is a multi-disciplinary open access archive for the deposit and dissemination of scientific research documents, whether they are published or not. The documents may come from teaching and research institutions in France or abroad, or from public or private research centers.
L'archive ouverte pluridisciplinaire HAL, est destinée au dépôt et à la diffusion de documents scientifiques de niveau recherche, publiés ou non, émanant des établissements d'enseignement et de recherche français ou étrangers, des laboratoires publics ou privés. 


\section{Characterizing deep hydrothermal fluid circulation in the Upper Rhine Graben (France) with electromagnetic methods}

\section{Introduction}

Electricity and heat production using Enhanced Geothermal System (EGS) technology rely on our knowledge and prediction capacity of hydrothermal fluid property, mainly temperature and flow rate. Most of hydrothermal fluid properties are obtained from post-drilling phases, whereas proxy information is hard to access in an economically viable way. The main challenge is then to develop methods to access these properties at the early stage of the exploration phase.

Deep fractured reservoirs are usually characterized by non-destructive geophysical methods (seismic, gravity, etc.). However, these techniques have a low sensitivity to geothermal fluids and so, do not predict accurately the geothermal resource, and more particularly the flowrate, before drilling operation.

Due to their sensitivity to fluids and particularly brine water in rocks (Archie, 1942), passive electromagnetic (EM) techniques (e.g. Magnetotellurics or MT) or active (Controlled-Source Electromagnetic or CSEM) have been traditionally used to investigate the subsurface conductivity. EM methods have shown to be effective to characterize geothermal reservoir geometry in volcanic area (Munoz, 2014), hydrocarbon reservoir geometry in offshore sedimentary area or onshore mineral exploration. Nevertheless, the ability of EM methods to image targets with high geothermal potential in deep fractured reservoir and in a high man-made noise environment still need to be demonstrated. Indeed, CSEM sources must compete with high noise levels and a conductive sedimentary cover resulting in low signal to noise ratio. In the framework of DEEP-EM project, we propose to adapt EM methods layout and imaging techniques to overcome these constraints and so reduce the risk of EGS projects exploration.

The benefit of the developed method will not be limited to deep fractured reservoirs but could be adapted to different settings like shallow geothermal reservoirs (e.g. Dogger layer in Paris Basin) and used to characterize other kinds of fluid content (e.g. CO2 storage).

\section{Design of the CSEM exploration campaign using electrical resistivity logs}

For about thirty years, the Upper Rhine Graben (UGR) has been a main target for research on geothermal exploration in deep fractured formations. Favorable targets are mainly deep and fractured hard rocks. In the last twenty years, geothermal activity in the Upper Rhine Graben has been on-going with several French (Soultz-sous-Forêts, Rittershoffen, Vendenheim, Illkirch), German (Landau, Insheim, Bruchsal, Bruhl) and Swiss (Riehen, Basel) deep geothermal sites which are active from exploration to exploitation. All these projects deal with deep fractured geothermal reservoirs located within Triassicsediments and/or crystalline basement (Aichholzer and al., 2016).

Predictive modelling suggests that CSEM anomalies in sedimentary basins are controlled at first order by the sedimentary cover resistivity (layer geometry and resistivity variation between and within the layers) and in a second order by hydrothermal fluid circulations. Hence, the knowledge of resistivity variations in the sedimentary cover is required to properly image deep fluid flow with high accuracy.

The Soultz-sous-Forêts and Rittershoffen (Alsace, France) geothermal wells data have provided electrical resistivity logs to study the electrical signature of deep fluid circulations. Preliminary results show a conductive trend for hydrothermally altered fractured zones and a highly resistive trend for unaltered facies (Figure 1) and hence a strong link between conductivity and permeable zones.

These results will help to design an appropriated acquisition campaign, since investigation and resolution depth in EM measurements mainly depend on formation resistivity and on the transmitted frequency (Zonge and Hughes, 1991). 


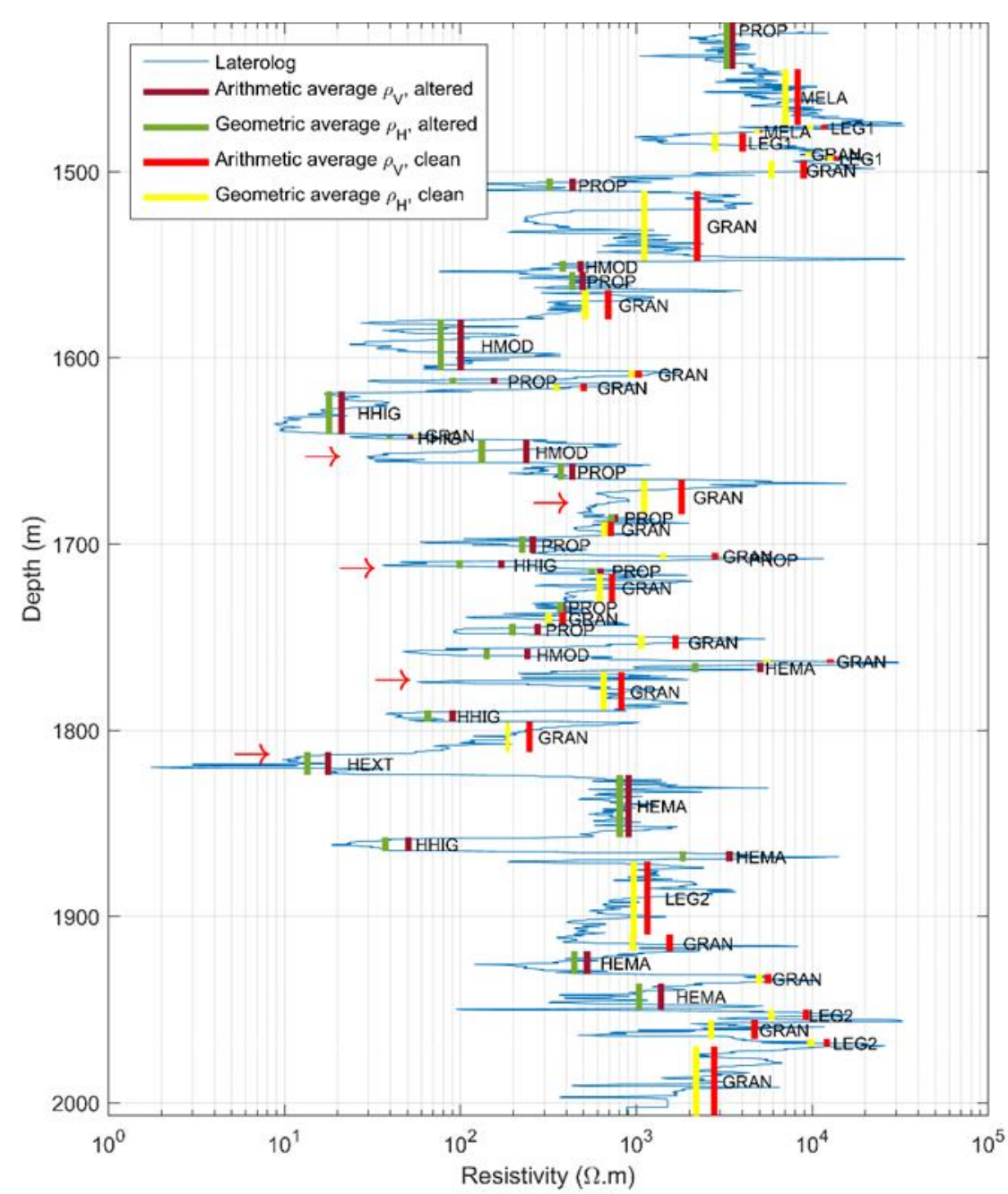

Figure 1 GPKI resistivity laterolog in granite (geothermal well from Soultz-sous-Forêts) linked with cuttings observation. Red arrows correspond to the position of the main permeable fracture zones (Genter and al., 1997). Red and yellow line correspond to resistivity average for unaltered facies and green and purple to altered facies. GRAN: Biotite porphyritic standard granite. PROP: Propylitised biotite porphyritic granite. MELA: Biotite-rich granite. LEG1: Leucogranite 1. LEG2: Leucogranite 2. HEMA: Hematitised biotite porphyritic granite. HMOD: Moderately altered granite. HHIG: Highly altered granite. HEXT: Extremely altered granite (Traineau and al., 1991).

\section{Field trial and exploration campaign}

In July 2019, a CSEM/MT field trial (12 receivers (RX) installed every kilometre between Soultz-sousForêts and Rittershoffen plants) was performed to validate the design of a large-scale exploration campaign. The main goal of this test was to prove that despite the anthropogenic noise in the area, the CSEM setup was appropriate to image resistivity variations in the deep fractured granitic basement. In particular, the distance $(\sim 3 \mathrm{~km})$ between electrodes transmitter $(\mathrm{TX})$ was increased that resulted in an amplification of the dipole moment (product of dipole length by an inject current intensity) and allowed to obtain a good signal to noise ratio more than $10 \mathrm{~km}$ away from the TX.

CSEM data were inverted with MARE2DEM software (Key, 2016) and inversion results showed that the signal to noise ratio was sufficiently low to image resistivity variations within the basement. During the inversion process, the basement/sediments interface defined by seismic imaging was used to constrain the subsurface geometry to improve the vertical resolution of resistivity. Interestingly, inverted resistivity shows a good match with electrical resistivity logs within the sedimentary cover and granitic basement (Figure 2). 


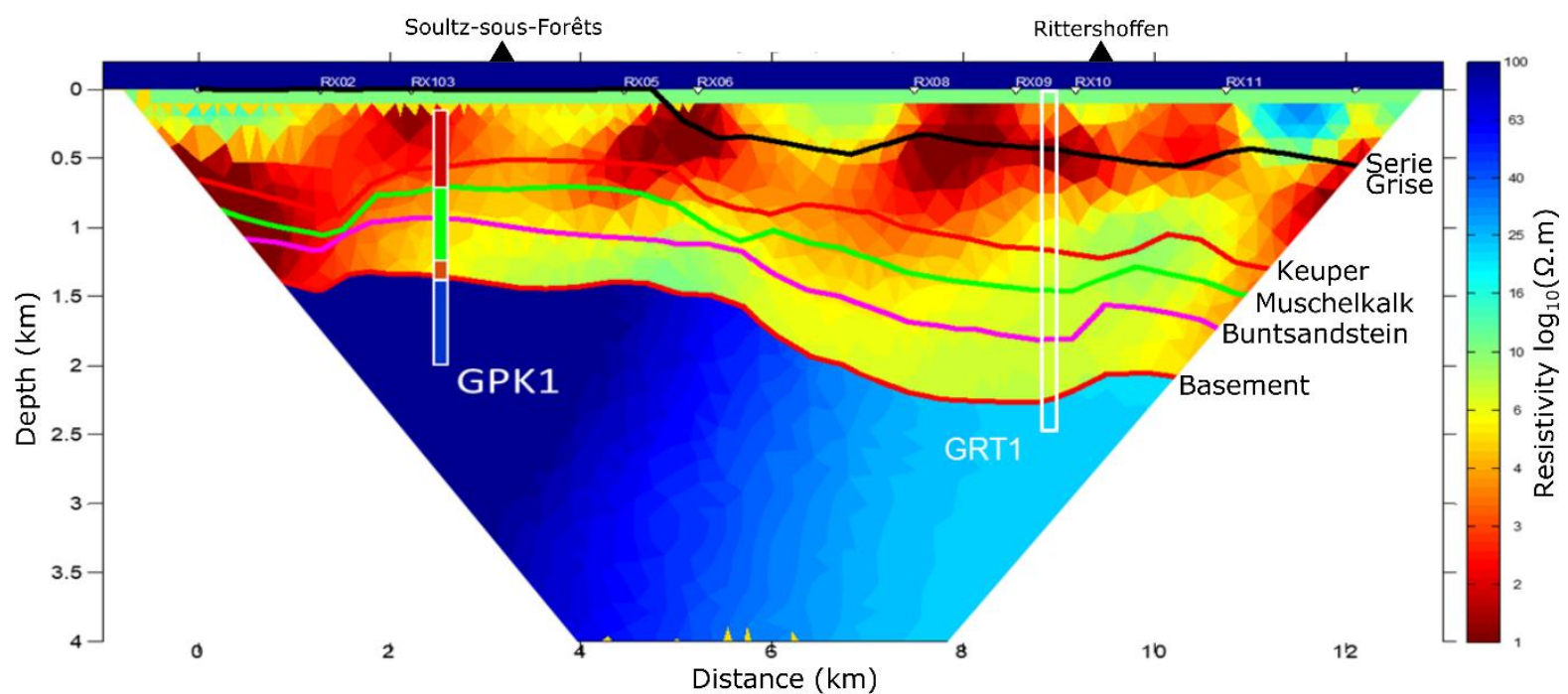

Figure 2 CSEM/MT results from 2019 acquisition linked with the main formation isohypses. GPK-1 (Soultz-sous-Forêts) and GRT-1 (Rittershoffen) geothermal wells are located on the W-E profile (Figure 3). Electrical resistivity logs from GPK-1 show a good match with the inverted resistivity.

Several geothermal power plants projects consisting of quadruplets ( 2 injection wells and 2 production wells) are planned in Northern Alsace with the aim to reach temperatures over $150^{\circ} \mathrm{C}$ and flow rate over $250 \mathrm{~m} 3 / \mathrm{h}$ per well. The results of this field trial have been used to define the acquisition parameters of a large-scale exploration campaign ( 6 transmitters and 100 receivers spread on $150 \mathrm{~km}^{2}$, Figure 3 ) carried out in October 2020 and that covered the whole exploration license and aims at providing additional subsurface information to prioritize the geothermal areas of interest. Results from the 3D inversion of this dataset will be available by the time of the conference.

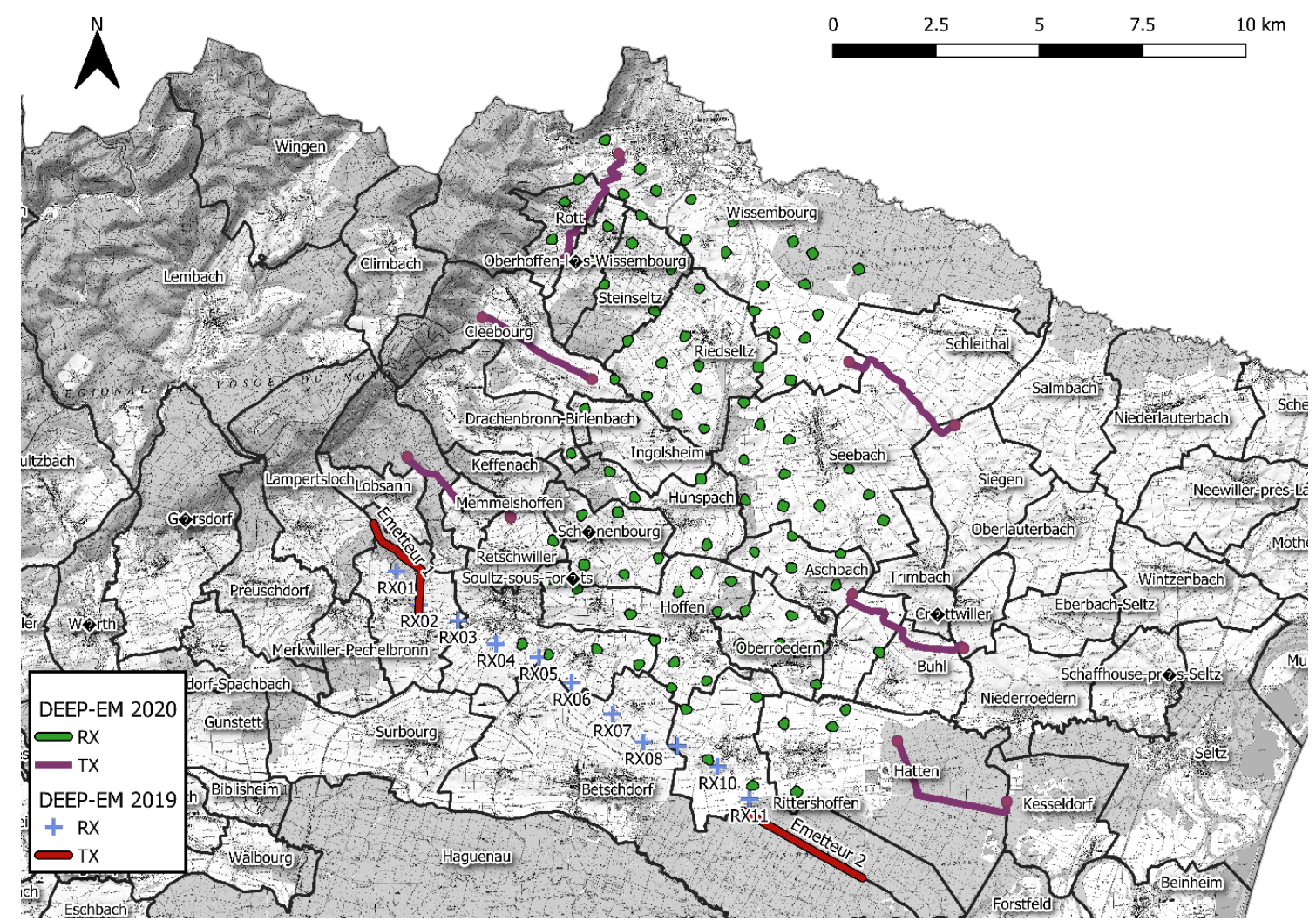

Figure $33 D$ CSEM/MT exploration campaign planned in October 2020 and location of 2019 acquisition campaign. 


\section{Conclusions}

EM methods have been traditionally used to characterize shallow geothermal targets in volcanic context. The aim of DEEP-EM project is to develop these methods in order to use them for deep geothermal targets in sedimentary basins. Preliminary EM results showed the ability of resistivity measurements to provide information on deep fluid circulations at two different scales (borehole and reservoir). Electrical resistivity logs reveal a clear separation between altered/unaltered facies and furthermore a link between conductivity and permeable zones. At the reservoir scale, a CSEM field trial demonstrated the ability of the technique to image resistivity variations underneath a thick sedimentary cover $(>1.4 \mathrm{~km})$. These results have been used to design the acquisition of a large-scale EM exploration campaign in 2020 and provide additional subsurface information to prioritize the geothermal areas of interest.

\section{Acknowledgements}

The authors wish to thank the ADEME (French Agency of Energy and Environment) in the framework of the DEEP-EM project. The authors acknowledge the GEIE EMC and ECOGI for their grateful help in this project.

\section{References}

Aichholzer, C., Duringer, P., Orciani, S. and Genter, A.: New stratigraphic interpretation of the Soultzsous-Forêts 30-year-old geothermal wells calibrated on the recent one from Rittershoffen (Upper Rhine Graben, France). Geotherm Energy 4, 13, (2016).

Archie, G. E.: The Electrical Resistivity Log as an Aid in Determining Some Reservoir Characteristics. Petroleum Transactions of the AIME, 146, (1942), 54-62.

Genter, A., Traineau, H. and Artignan, D.: Synthesis of geological and geophysical data at Soultz-sousForêts (France). Rapport BRGM R39440, (1997), 36.

Key, K.: MARE2DEM: a 2-D inversion code for controlled-source electromagnetic and magnetotelluric data. Geophysical Journal International, 207, (2016), 571-588.

Munoz, G.: Exploring for geothermal resources with electromagnetic methods. Surveys in geophysics, 35(1), (2014), 101-122.

Traineau, H., Genter, A., Cautru, J.P., Fabriol, H. and Chevremont, P.: Petrography of the granite massif from drill cutting analysis and well log interpretation in the HDR borehole GPK1 (Soultz, Alsace, France). Geothermal Science and Technology, 3, (1991), 1-29

Zonge, K.L., and Hughes, L.J.: Controlled Source Audio-Frequency Magnetotellurics. Investigations in Geophysics, (1991), 713-810. 